\title{
Meningkatkan Hasil Belajar Siswa Melalui Model Pembelajaran Interaktif Berbasis Aktivitas Pada Mata Pelajaran PKn Kelas VI SD Negeri 111/IX Jaluko Kabupaten Muaro Jambi
}

Sofiah

SD Negeri III/IX Jaluko Kabupaten Muaro Jambi

sofiahs414@gmail.com

\begin{abstract}
Abstrak
Dengan menggunakan model pembelajaran interaktif berbasis aktivitas, siswa cenderung lebih aktif karena suasana belajar mengarah kepada siswa menemukan hasil pemahaman melalui suatu interaksi, mudah dalam memahami materi ajar, karena dibantu melalui media belajar yang kongkrit.Setelah dilakukan tindakan-tindakan dalam penelitian ini, hasil belajar siswa mengalami peningkatan yang sangat signifikan dari hasil ketuntasan awal pada pra siklus meningkat pada siklus Idan kembali meningkat pada siklus II.Pada pra siklus yang tuntas belajar hanya sebesar 56,25\% atau 9 siswa, sedangkan siswa yang belumtuntas 44,75 atau 7 siswa. Pada siklus 1 nilai rata-rata meningkat yaitu sebesar 68,75 dengan ketuntasan belajar sebesar $62,50 \%$ atau 10 anak sedangkan yang belum tuntas $33,50 \%$ atau 6 siswa. Pada siklus 2 ketuntasan belajar mengalami peningkatan hingga mencapai 87,50\% atau 14 siswa sedangkan yang belum tuntas $12,50 \%$ atau 2 siswa.Hasil penelitian membuktikan bahwa penerapan pembelajaran menggunakan model pembelajaran interaktif berbasis aktivitas dapat meningkatkan hasil belajar siswa padamata pelajaran PKn kelas VI SD Negeri 111/IX Jaluko Kabupaten Muaro Jambi.
\end{abstract}

Kata kunci:Hasil Belajar, Model Interatif Berbasis Aktivitas, PKn.

\section{Pendahuluan}

Dalam proses mengajar guru menjadi pemeran utama dalam menciptakan situasi interaktif yang edukatif, yakni interaksi antara guru dengan siswa, dan dengan sumber pembelajaran dalam menunjang tercapainya tujuan belajar. Untuk terwujudnya proses belajar mengajar seperti itu upaya guru untuk mengaktualisasikan kompetensinya secara professional merupakan keniscayaan.

PKn sebagai salah satu bidang studi yang memiliki tujuan membekali siswa untukmengembangkan penalarannya disamping aspek nilai dan moral, banyak memuat materi sosial bersifat hapalan sehingga pengetahuan dan informasi yang diterima siswa sebatas produk hapalan semata. Sifat pelajaran PKn membawa konsekuensi terhadap proses belajar mengajar yang didominasi oleh pendekatan ekspositoris, terutama guru menggunakan metode ceramah sedangkan siswa kurang terlibat dalam proses pembelajaran atau cenderung pasif. Dalam metode ceramah terjadi dialog imperaktif. Padahal, dalam proses belajar mengajar keterlibatan siswa harus secara totalitas yaitu dengan melibatkan pikiran, penglihatan,pendengaran, dan psikomotorik (siswa, salah satunya sambil menulis). Jadi, dalam proses belajar 
mengajar, seorang guru harus mengajak siswa untuk mendengarkan, menyajikan media yang dapat dilihat, memberi kesempatan untuk menulis dan mengajukan pertanyaan atau tanggapan sehingga terjadi dialog, kreatif yang menunjukkan proses belajar mengajar yang interaktif positif. Situasi belajar seperti ini dapat tercipta melalui penggunaan pendekatan partisipatoris.

Proses belajar mengajar mempunyai makna dan pengertian yang lebih luas dari pada pengertian mengajar itu sendiri, karena didalamnya tersirat satu kesatuan kegiatan yang tidak terpisahkan antara siswa yang belajar dengan guru yang mengajar, sehingga terjalin dalam bentuk interaksi edukatif. Peran guru dalam pembelajaran PKn mempunyai hubungan erat dengan cara mengaktifkan siswa dalam belajar, terutama dalam proses pengembangan siswanya, salah satunya mengembangan siswa berpikir, siswa sosial dan siswa praktis. Siswa berpikir dikembangkan untuk melatih siswa berpikir logis dan sistematis melalui proses belajar mengajar dengan model pengembangan berpikir kritis, siswa sosial dan praktis dikembangkan melalui model dialog kreatif. Ketiga siswa tersebut dapat dikembangkan dalam situasi belajar mengajar yang aktif antara guru dengan siswa dan siswa dengan siswa.

Permasalah yang muncul disekolah saat melaksanakan pembelajaran siswa dalam bidang PKn adalah kurangnya keinginan siswa dalam mengikuti proses belajar mengajar, siswa cenderung kurang serius dalam memfokuskan diri mengikuti materi pembelajaran. Hal ini karena dalam pelaksanaannya guru menjadikan buku sebagai sumber tunggal kegiatan belajar mengajar di kelas, disamping itu guru hanya menggunakan metode ceramah dalam menyampaikan dan menjelaskan materi pembelajaran PKn dengan mengesampingkan media peraga atau contoh gambar yang merupakan sarana pengetahuan nyata bagi siswa,

Berdasarkan studi pendahuluan peneliti ditemukan permasalahan yang dihadapi oleh siswa yaitu kurangnya keinginan siswa untuk mengikuti proses belajar mengajar, beberapa masalah yang terjadi dalam proses belajar mengajar diantaranya (1) kurangnya interaksi antara guru dan siswa; (2) penguasaan guru tentang metode pengajaran masih belum maksimal; (3) siswa cenderung pasif dan kurangnya motivasi; (4) metode yang digunakan dalam mengajar belum variatif/ monoton yang kurang sesuai dengan karakteristik dan kebutuhan siswa; (5) siswa cenderung hanya menghafal dan bukan memahami konten pelajaran; (6). Keberadaan siswa untuk belajar cenderung bertolak dari rasa takut kepada guru dan orang tua daripada keinginan personal untuk mendapatkan ilmu pengetahuan.

Adapun yang menjadi rumusan masalah dalam penelitian tindakan kelas ini yaitu bagaimana pembelajaran interaktif berbasis aktivitas untuk meningkatkan hasil belajar siswa kelas VI mata pelajaran PKn pada materi nilai-nilai juang dalam perumusan pancasila. Tujuan penelitian yaitu untuk mengetahui pembelajaran interaktif berbasis aktivitas dapat meningkatkan hasil belajar siswa pada mata pelajaran PKn kelas VI SD 111/IX Jaloku Kabupaten Muaro jambi. Manfaat penelitian yaitu bagi guru sebagai bahan masukan bahwa pembelajaran interaktif berbasis aktivitas dapat dijadikan salah satu alternatif solusi meningkatkan hasil belajar mata pelajaran PKn materi pokok nilai-nilai juang dalam perumusan pancasila, bagi siswa dapat mengembangkan potensi diri secara optimal terutama dalam belajar PKn ke depannya, bagi sekolah sebagai masukan dalam upaya perbaikan proses pembelajaran, sehingga berdampak pada peningkatan mutu sekolah serta memberikan konstribusi akademis dalam pengembangan teori bidang ilmu yang diteliti bagi praktisi

Tujuan pembelajaran interaktif berbasis aktivitas sebagaimana Harlen, (2010: 376) diantaranya (1) meningkatkan partisipasi aktif siswa dalam pembelajaran; (2) 
meningkatkan pemahaman sosial antara siswa dengan lingkungan sekitar; (3) mendorong siswa untuk dapat menemukan dan menyelidiki sendiri konsep yang dipelajari yang mudah di ingat dan tidak mudah dilupakan siswa; (4) membantu siswa membentuk cara kerja bersama yang efektif, saling membagi informasi, serta mendengar dan menggunakan ide-ide orang lain; dan (5) melatih siswa belajar berpikir analitis dan mencoba memecahkan masalah yang dihadapi sendiri.

Kegiatan pembelajaran interkatif berbasis aktivitas didasarkan pada beberapa prinsip sebagaimana Slavin, Robert (2009: 404) yaitu (1) somatis yaitu siswa mengalami aktivitas fisik yang memungkinkan siswa berinteraksi dengan orang lain secara berpasangan atau kelompok, dari satu tempat ke tempat lain baik didalam maupun diluar kelas; (2) auditory yaitu memungkinkan siswa untuk mendengar secara aktif dari berbagai sumber informasi; (3) visual yaitu memungkinkan siswa untuk melakukan pengamatan gambar atau lingkungan sekitar; (4) intelektual yaitu memungkinkan siswa untuk melakukan proses tanya jawab terhadap lingkungan belajarnya.

Pembelajaran berbasis aktivitas memiliki karakteristik umum dalam pelaksanaan pembelajaran oleh guru baik di dalam kelas maupun diluar kelas. Karakteristik pembelajaran interaktif berbasis aktivitas sebagaimana Usman, (2011: 43) yaitu bersifat (1) interaktif dan inspiratif; (2) menyenangkan, menantang, danmemotivasi siswa untuk berpartisipasi aktif; (3) kontekstual dan kolaboratif; (4) memberikan ruang yang cukup bagi prakarsa, kreativitas, dan kemandirian siswa; dan (5) sesuai dengan bakat, minat, kemampuan, dan perkembangan fisik serta psikologis siswa.

Dalam rangka meningkatkan kualitas proses belajar mengajar dan hasil pembelajaran dengan pembelajaran interaktif berbasis aktivitas Harlen, (2010:343) mengemukakan (1). siswa aktif dalam kegiatan belajar, karena berpikir dan menggunakan kemampuan untuk menemukan hasil akhir; (2) siswa memahami bahan pelajaran dengan baik, karena mengalami sindiri proses menemukannya; (3) siswa menemukan sendiri konsep, prinsip atau teori yang dapat menimbulkan rasa puas; (4) siswa memperoleh pengetahuan dengan metode penemuan akan lebih mampu mentranfer pengetahuannya kepada berbagai konteks; (5) melatih siswa untuk lebih banyak belajar mandiri dan bertanggung jawab.

Pembelajaran adalah proses interaksi antara siswa dengan siswa, antara siswa dengan guru dan antara siswa dengan sumber belajar pada suatu lingkungan belajar, (Wardani, 2006: 121). Didalam pembelajaransiswa didorong untuk menemukan sendiri dan mentransformasikan informasi kompleks, mengecek informasi baru dengan yang sudah ada dalam ingatan, dan mengembangkannya menjadi informasi atau kemampuan yang sesuai dengan lingkungannya. Pembelajaran menganut pandangan dasar bahwa pengetahuan tidak dapat dipindahkan begitu saja dari guru kepada siswa. Siswa adalah subjek yang memiliki kemampuan untuk secara aktif mencari, mengolah, mengkonstruksi, dan menggunakan pengetahuan untuk mengatasi masalah. Untuk itu pembelajaran harus berkenaan dengan kesempatan yang diberikan kepada siswa untuk mengkonstruksikan pengetahuan dalam proses kognitifnya secara utuh.

Motode pembelajaran interaktif berbasis aktivitas sering dikenal dengan nama pendekatan pertanyaan anak. Motode ini dirancang agar siswa akan bertanya dan kemudian menemukan jawaban pertanyaan dengan mandiri. Pengembangan model pembelajaran interaktif berbasis aktivitas dalam mata pelajaran PKn dapatdilakukan oleh guru pada semua pokok bahasan, dengan memperhatikan sembilan hal. 


\section{Faktor Minat dan Perhatian}

Kondisi belajar mengajar yang interaktif ditandai dengan adanya minat dan perhatian siswa dalam belajar, yang juga merupakan faktor utama penentu keaktifan siswa. Menurut Mursell (Harlen, 1992: 333) terdapat 22 macam minat yang berguna bagi guru dalam memberikan pelajaran kepada siswa, salah satunya anak memiliki minat terhadap belajar sementara guru dapat berusaha membangkitkan minattersebut dengan cara memilih dan menentukan bahan pengajaran sebagai key concept untuk menciptakan perhatian siswa secara total. Upaya memusatkan perhatian siswa dapat dilakukan dengan cara mengajukan masalah.

\section{Faktor Motivasi}

Sebagaimana Maslow, A (Hamdi, M, 2011: 201) mengemukakan bahwa motivasi adalah suatu proses untuk menggaitkan motif-motif menjadi perbuatan guna mencapai tujuanatau keadaan dan kesiapan dalam diri seseorang yang mendorong tingkah lakunya untuk berbuat sesuatu dalam mencapai tujuan tertentu. Sedangkan motif adalah daya dalam diri seseorang yang mendorongnya untuk melakukan sesuatu. Motivasi belajar dapat timbul dari dalam diri siswa (motivasi intrinsic) dan pengaruh dari luar dirinya (motivasi ekstrinsik). Dalam konteks ini guru berperan sebagai motivator untuk menumbuhkan kedua motivasi tersebut agar siswa mempunyai potensi rasa ingin tahu (sense of curiosity), rasa ingin maju dan lain-lain. Sedangkan motivasi eksterinsik dapat timbul dari upaya guru melalui penerapan ganjaran dan penghargaan atau reward serta hukuman atau punishment (model S$\mathrm{R}$ ), yang diorentasikan pada upaya memotivasi siswa untuk belajar.

\section{Faktor Latar Atau Konteks}

Belajar berdasarkan realita akan menarik, belajar dimulai dari yang sederhana dapat memotivasi siswa, dan belajar berdasarkan pengalaman dapat mengikutsertakan siswadidalamnya. (Kusnan, 2010:86). Dalam proses belajar mengajar, guru perlu mencari tahu pengetahuan, siswa dan sikap yang telah dimiliki oleh siswa sehingga tidak terjadi pengulangan materi pelajaranyang hanya menimbulkan kebosanan bagi siswa. Guru dituntut untuk mengembangkan pengetahuan dan siswa serta sikap yang dimiliki masing-masing siswa.

\section{Faktor Perbedaan Individu}

Pada hakekatnya siswa adalah individu yang unik yang memiliki karakteristik berbeda-beda, baik kecerdasan, minat, bakat, sifat, kegemaran dan latar belakang, yang dapat mempengaruhi proses belajar mengajar. Mursell, (Harlen,2010:340) mengemukakan perbedaan siswa secara vertikal dan secara kualitatif. Perbedaan vertikal, yaitu berkenaan dengan intelegensi umum dari siswa, sedangkan perbedaan kualitatif berkenaan dengan bakat dan minatnya. Mengingat adanya perbedaan tersebut, guru hendaknya menyadari dan memaklumi apabila ada siswa yang berhasil dengan baik, atau bahkan sebaliknya mengalami kesukaran memahami pelajaran.Dalam hal ini, guru harus tetap memperhatikan persamaan dan perbedaan siswa dengan cara mengoptimalkan pengembangan kemampuan masing-masing siswa. Salah satu cara yang dapat ditempuh adalah bantuan khusus atau menjadikan siswa saling membelajarkan, artinya siswa yang telah memahami membantu siswa yang belum memahami sehingga dengan adanya perbedaan tersebut jugamenciptakan interaksi pembelajaran dari siswa ke siswa.

\section{Faktor Sosialisasi}

Sosialisasi atau proses hubungan sosial, pada tahap-tahap perkembangan siswa ditandai dengan keinginan untuk berusaha menjalin hubungan dengan siswa yang lainnya. Dalam hal ini terdapat suatu hal yang perlu mendapat perhatian guru ketika melangsungkan proses belajar mengajar di kelas yaitu siswa akan merefleksikan keinginan dengan cara mengobrol dengan siswa lainnyayang berujung kegaduhan di dalam kelas sehingga keefektifan belajar menjadi terhambat. 


\section{Faktor Belajar Sambil Bermain}

Bermain merupakan kebutuhan bagi setiap anak, karena bermain merupakan keaktifan yang menimbulkan kegembiraan dan menyenangkan. Proses belajar mengajar yang dilakukan dalam suasana bermain akan mendorong siswa aktif belajar sehingga pengetahuan, keterampilan, sikap dan daya fantasi anak cenderung berkembang.

\section{Faktor Belajar Sambil Bekerja}

Pentingnya aktivitas belajar siswa dalam proses belajar mengajar diungkapkan John Dewey, (Usman, 2011: 421) melalui metode proyeknya dengan konsep learning by doing. Aktivitas yang dimaksud adalah aktivitas jasmaniah dan aktivitas mental, yang digolongkan ke dalam lima kelompok yaitu: (a). Aktivitas visual (Visual activities), yaitu membaca, menulis, melakukan eksperimen dan diskusi. (b). Aktivitas lisan (Oral Activities), seperti bercerita, membaca sajak, tanya jawab dan diskusi. (c). Aktivitas Mendengarkan (Listening Activities), seperti mendengarkan penjelasan guru, mendengarkan ceramah dan pengarahan. (d). Aktivitas Gerak (Motor Activities), seperti simulasi, bermain peran, membuat peta atau tabel $\mathrm{dn}$ grafik. (e). Aktivtas Menulis (Writing Activties), seperti mengarang, membuat ringkasan, dan membuat makalah.

\section{Faktor Inkuiri}

Pada dasarnya siswa memiliki potensi berupa dorongan untuk mencari dan menemukan sendiri (sense of inquiry), baik fakta maupun data atau informasi yang akan dikembangkannya dalam bentuk cerita atau menyampaikannya kepada siswa lainnya. Dengan demikian peran guru memberikan kesempatan yang sama kepada setiap siswa untuk menemukan sendiri informasi yang ada kaitannya dengan materi pelajaran dengan menyampaikan informasi mendasar dan memicu siswa untuk mencari informasi selanjutnya.

\section{9. $\quad$ Faktor Memecahkan Masalah}

Setiap anak menyukai tantangan (sense of Chalanger), demikian pula halnya dengan siswa dalam belajar. Belajarmemiliki tantangan yang sesuai dengan tingkat kemampuan siswa yang akan mendorong siswa untuk belajar. Namun demikian tantangan yang beratakan mematahkan semangat dan membuat siswa tidak betah belajar. Dalam proses belajar mengajar, tantangan tersebut dapat diciptakan oleh guru dengan mengajukan situasi bermasalah agar siswa peka terhadap masalah. Guru dalam proses belajar mengajar yang intraktif dapat mengembangkan teknik bertanya efektif atau melakukan dialog kreatif dengan mengajukan pertanyaan kepada siswa. Sifat pertanyaan dapat mengungkapkan sesuatu atau memiliki sifat inkuiri sehingga melalui pertanyaan yang diajukan, siswa dikembangkan kemampuannya kearah berpikir kreatif dalam menghadapi sesuatu. Beberapa komponen yang harus dikuasai oleh guru dalam menyampaikan pertanyaan sebagaimana Suciati, (2010: 32) yaitu: (a). Pertanyaan harus mudah dimengerti oleh siswa;(b). Memberikan acuan;(c). Memusatkan perhatian; (d). Pemidahan giliran dan penyebaran;(e). Pemberian waktu berpikir kepada siswa;dan (f). Pemberian tuntunan.

Sedangkan jenis pertanyaan untuk pengembangan model dialog kreatif sebagaimana Winaputra, (2010: 444) terdapat enam jenis yaitu: (a). Pertanyaan mengingat; (b). Pertanyaan mendeskripsikan; (c). Pertanyaan menjelaskan;(d). Pertanyaan sintesis;(e). Pertanyaan menilai; dan (f). Pertanyaan terbuka. Untuk meningkatkan interaktif berbasis aktivitas dalam proses belajar mengajar, guru hendaknya mengajukan pertanyaan dengan memberi kesempatan kepada siswa untukmendiskusikan jawabannya dan menjadi dinding pemantul atas jawaban siswa. 
Hasil belajar siswa adalah hasil belajar yang dinyatakan dalam bentuk nilai atau dalam bentuk skor, setelah siswa mengikuti pelajaran. Sudjana (2011: 43) mendifinisikan hasil belajar sebagai kemampuan yang dimiliki siswa, yang ditunjukkan melalui perubahan tingkah laku (behavioral change), setelah siswa mengalami pengalaman belajar. Wujud tingkah laku sebagai hasil belajar dimaksud misalnya dari tidak tahu menjadi tahu, dari tidak mengerti menjadi mengerti, atau dari tidak memahami menjadi paham.

Pembelajaran yang berhasil ditunjukkan oleh tercapainya hasil belajar yangoptimal. Wujud pencapaian hasil belajar siswa lazimnya dinyatakan dengan nilai hasil belajar, salah satunya adalah nilai ulangan harian. Sesuai dengan nama atau istilahnya, nilai ini diperoleh siswa setelah pelaksanaan suatu ulangan harian. (Sudjana, 2010: 54).

\section{Metode}

Jenis penelitian ini yaitu penelitian tindakan kelas (action research) penelitian tindakan kelas merupakan penelitian yang dilakukan oleh guru di dalam kelasnya sendiri melalui refleksi diri dengan tujuan untuk memperbaiki kinerjanya sebagai guru sehingga kualitas proses dan hasil belajar siswa meningkat (Cresswell, 2008), lokasi penelitian yaitu SDN no 111/IX Jaluko Kabupaten Muaro Jambi, waktu penelitian yaitu semester dua tahun ajaran 2012/ 2013, subjek penelitian yaitu siswa kelas VI yang berjumlah 16 siswa terdiri dari 9 laki-laki dan 8 perempuan. Teknik pengumpulan data menggunakan penilaian tertulis untuk memperoleh data hasil belajar PKn mengenai kenampakan alam dan sosial negara-negara tetangga, observasi kinerja guru dalam bentuk indikator keberhasilan guru dan aktivitas belajar siswa dalam bentuk indikator keberhasilan siswa, prosedur penelitian terdiri dari rencana (planning); pelaksanaan tindakan (action); pengamatan/ observasi (observation); dan refleksi (reflection) (Creswell, 2008). Data hasil dianalisis dengan persentase sederhana.

\section{Siklus I}

1. Perencanaan

Rencana perbaikan pembelajaran yang peneliti susun antara lain meliputi: mengadakan tanya jawab dan diskusi tentang kenampakan alam, sosial budaya negara-negara tetangga. siswa berdiskusi dan melakukan tanya jawab tentang kenampakan alam dan sosial negara-negara tetangga.

2. Pelaksanaan

Adapun pelaksanaan dari rencana pembelajaran antara lain sebagai berikut:Guru menjelaskan materi dengan melakukan tanya jawab dengan siswa membimbing siswa dalam mengerjakan LKS membahas LKS untuk mengukur kemampuan siswa dalam menerima pelajaran dari guru.

\section{Pengamatan}

Adapun beberapa aspek yang diamati antara lain: (a). Menjelaskan konsep kenampakan alam; (b) memimpin diskusi kelompok; (c) membimbing diskusi siswa; dan (d). Menarik kesimpulan dari pelaksanaan diskusi.

\section{Refleksi}


Tahapan refleksi digunakan untuk melihat kekurangan dan kelebihan yang timbul pada perbaikan pembelajaran dan sekaligus menentukan dilakukan atau diakhirinya tindakan.

\section{Hasil dan Pembahasan}

Pada pra pembelajaran jumlah siswa yang tidak tuntas dalam mengikuti pembelajaran sangat tinggi. Setelah dilaksankan perbaikan pembelajaran pada siklus Ipersentase ketuntasan belajar siswa meningkat sebesar $62,50 \%$ atau 10 siswa yang tuntas dan 6 siswa belum tuntas. Pada siklus II ketuntasan belajar siswa mengalami peningkatan yang sangat signifikan yaitu sebesar $87,50 \%$.

Setelah dilakukannya penelitian tindakan kelas ini barulah ditemukan beberapa kekuatan dan kelemahan pada diri peneliti sebagai guru di tempat penelitian berlangsung.Setelah mengadakan perbaikan pembelajaran yang ditemukan melalui tahapan refleksi di setiap siklusnya, peniliti lebih rinci dalam melihat permasalahan yang sering timbul pada pembelajaran pada umumnya, hasil tersebut mengindikasikan umpan balik bagi peneliti sebagai seorang guru untuk segara membuat rencana perbaikan yang bisa meminimalkan masalah yang ada.

Penerapan model pembelajaran interaktif berbasis aktivitas untuk meningkatkan hasil belajar siswa dapat dilakukan dengan mengawalinya dengan membuat rencana pelaksanaan pembelajaran (RPP), menentukan konsep materi yang akan diajarkan kepada siswa, mencari dan merumuskan masalah yang sesuai dengan konsep tersebut, serta merencanakan strategi pembelajaran yang sesuai atau yang cocok.

Mengacu pada model yang digunakan, maka selama proses kegiatan belajar mengajar di kelas siswa dapat memusatkan perhatiannya pada pokok bahasan yang akan dijelaskan. Siswa memperoleh pengalaman yang dapat membentuk ingatan yang kuat, siswa terhindar dari kesalahan dalam mengambil suatu kesimpulan, pertanyaan-pertanyaan yang timbul dapat dijawab sendiri oleh siswa pada saat dilaksanakannya evaluasi, apabila terjadi keraguan siswa dapat menanyakan secara langsung kepada guru, kesalahan yang terjadi dari hasil ceramah dapat diperbaiki karena langsung terjadi interaksi antara guru dan siswa dalam proses belajar mengajar.

Kesalahan yang terjadi dari hasil ceramah dapat diperbaiki dengan cara: (1). Mengadakan dialog dengan siswa dan membahas tentang materi yang telah diajarkan namun belum banyak yang memahaminya; (2). Memberikan tugas kelompok yang berupa lembar kerja kelompok, sehingga peneliti dapat mengukur kemampuan siswa dalam memahami pembelajaran; (3). Menggunakan metode pembelajaran yang bervariasi yaitu metode ceramah, metode tanya jawab, presentasi dan pemberian tugas secara kelompok.

Adapun tahapan-tahapan perencanaan perbaikan pembelajaran sebagai berikut: (1). Membuat rencana perbaikan pembelajaran secara tertulis yang berisi langkahlangkah pelaksanaan pembelajaran yang sekiranya siswa dapat dengan mudah mengikuti pembelajaran; (2). Menyiapkan lembar observasi yang merupakan hasil kesepakatan antara peneliti dengan teman sejawat yang bertindak sebagai observer/ pengamat; (3). Membuat lembar kerja kelompok untuk mengetahui tingkat keberhasilan pembelajaran siswa; (4). Mendeskripsikan nilai-nilai juang dalam perumusan pancasila dengan kalimat runtut; (5).Mengadakan tanya jawab mengenai hal-hal yang berhubungan dengan materi; (6) siswa mengerjakan soal postes; dan (7). Secara bersama-sama siswa membuat kesimpulan hasil belajar. 
Beberapa aspek yang diamati antara lain, sebagai berikut: (1). Menjelaskan konsep kenampakan alam; (2). memimpin diskusi kelompok; (3). Membimbing siswa berdiskusi dan (4) penarikan kesimpulan.

\section{Kesimpulan}

Berdasarkan uraian pembahasan dan hasil penelitian sebagaimana dikemukakan diatas mulai siklus 1 sampai siklus 2 mengenai penggunaan model pembelajaran interaktif berbasisi aktivitas, dapat penulis simpulkan bahwa:

1. Dengan menggunakan Model pembelajaran interaktif Berbasis Aktivitas, ternyata mampu meningkatkan hasil belajar siswa kelas VI SD Negeri 111/IX Jaluko Kabupaten Muaro Jambi

2. Melalui Model pembelajaran interaktif Berbasis Aktivitas, siswa dapat lebih aktif dalam kegiatan belajar, terutama pada mata pelajaran PKn.

\section{Saran}

Berdasarkan kesimpulan diatas serta hasil perbaikan pembelajaran, agar kegiatan belajar mengajar PKn yang membahas mengenai materi" Nilai-nilai juang dalam perumusan Pancasila" anak lebih aktif, kreatif dan memberikan hasil yang optimal bagi siswa. Maka ada beberapa saran yang dianggap perlu untuk peneliti sampaikan diantaranya:

1. Dalam kegiatan pembelajaran PKn sebaiknya guru menggunakan model pembelajaran interaktif berbasis aktivitas, karena dengan model pembelajaran tersebut terbukti dapat meningkatkan hasil belajar siswa;

2. Guru hendaknya menerapkan pembelajaran interaktif, terutama pada mata pelajaran PKn, karena dapat mengaktifkan siswa dalam pembelajaran.

\section{DAFTAR PUSTAKA}

Arikunto Suharsimi (2002) "Prosedur Penelitian Suatu Pendekatan Praktek. Jakarta:RinekaCipta

Creswell, John, W, (2008) "educationalresearch" Planning, Conducting, and Evaluating Quantitative and Qualitative research. Third Edition. America:Pearson Education. Inc

Hamdi, (2011). Teori kepribadian. Bandung: Upi SPs Press.

Harlen, (2010). Model Pembelajaran Interaktif. London: Kogon Page

Kusnan M.Rosyid,(2010).Pendidikan Kewarganegaraan Kelas VI. Jakarta: Intan Pariwara

Slavin, Robert. (2009) “Cooperative Learning. Teori, riset dan praktik”. Terjemahan. Bandung: Nusa Media

Suciati,(2010). Belajar dan Pembelajaran 2. Jakarta: Universitas Terbuka

Sudjana,(2011). Hasil Belajar. Jakarta: Rineka Cipta

Sugiyono, (2012). “metode penelitian kuantitatif kualitatif dan $R \& D ”$ Bandung: Alfabeta

Usman,(2011). Penerapan Model Pembelajaran Interaktif. Bandung: PustakaMartina. 
Wardani I.G.A.K, Wihardit Kuswaya, Nasution Noehi. (2006). Penelitian Tindakan Kelas (PTK). Jakarta: Universitas Terbuka

Winaputra, S Udin, (2010).Materi dan Pembelajaran. Jakarta: UniversitasTerbuka .Strategi Belajar Mengajar. Jakarta: Universitas Terbuka 